Louisiana State University

LSU Digital Commons

$9-17-2010$

Beneath The Salt Marsh Canopy: Loss Of Soil Strength With Increasing Nutrient Loads

R. Eugene Turner

Follow this and additional works at: https://digitalcommons.Isu.edu/oceanography_coastal_pubs

Part of the Oceanography Commons 


\title{
Beneath the Salt Marsh Canopy: Loss of Soil Strength with Increasing Nutrient Loads
}

\author{
R. Eugene Turner
}

Received: 8 May 2010 /Revised: 25 August 2010/Accepted: 31 August 2010 /Published online: 17 September 2010

(C) Coastal and Estuarine Research Federation 2010

\begin{abstract}
Although the broadly observed increase in nutrient loading rates to coastal waters in the last 100 years may increase aboveground biomass, it also tends to increase soil metabolism and lower root and rhizome biomass-responses that can compromise soil strength. Fourteen different multiyear field combinations of nutrient amendments to salt marshes were made to determine the relationship between soil strength and various nitrogen, phosphorus, and nitrogen+phosphorus loadings. There was a proportional decline in soil strength that reached $35 \%$ in the 60 - to $100-\mathrm{cm}$ soil layer at the highest loadings and did not level off. These loading rates are equivalent to those in the flow path of the Caernarvon river diversion, a major wetland restoration project near New Orleans; $12 \%$ of the wetlands in the flow path were converted to open water in 2005. The increased nutrient loading from the Mississippi River watershed this century has also driven the formation of the low oxygen zone (the "Dead Zone") that forms off the Louisiana-Texas shelf each summer. These results suggest that improving water quality in the watershed will aid the restoration of both offshore waters and coastal wetland ecosystems.
\end{abstract}

Keywords Wetland · Soil strength · Eutrophication · Sustainability $\cdot$ Louisiana

\footnotetext{
R. E. Turner $(\square)$

Coastal Ecology Institute,

and, Department of Oceanography and Coastal Sciences,

Louisiana State University,

Baton Rouge, LA 70803, USA

e-mail: euturne@1su.edu
}

\section{Introduction}

Among the attributes of coastal wetlands that society values is the ability to reduce wave energy and the height of storm surges, including those from hurricanes. The annual benefits of coastal wetlands in the form of storm surge reductions for all US coastal states are estimated to be about $\$ 8,236 \mathrm{ha}^{-1}$, for example, and $\$ 1,749 \mathrm{ha}^{-1}$ for Louisiana (Costanza et al. 2008). Plants and soil remain in place only if they have sufficient mechanical strength to anchor them when strong currents and winds push against the resisting aboveground biomass. If the erosive forces are too strong, then the soil layer either degrades in pieces or lifts off of the underlying basement material and an open-water habitat takes its place. One consequence of hurricanes in the microtidal Louisiana marshes is the creation of $2-\mathrm{m}$ high folds in the marsh (the "accordion effect") and "marsh-balls" (Lovelace and McPherson 1998), and to the re-distribution of mineral and organic sediments, as well as the surface debris (Turner et al. 2006).

It may seem that adding nutrients is a worthy management objective if the amount of aboveground biomass is a key factor determining whether wetlands are sustainable. Several studies, however, demonstrate that the soil ecosystem is affected in two important ways when the nutrient load is increased in coastal wetlands. One way is that the belowground biomass may be inversely related to nutrient loading. Root and rhizome biomass declines with increased nutrient loading in many freshwater, brackish, and saltwater coastal wetlands (Holm 2006; Darby and Turner 2008a, b; Langley et al. 2009). This result is consistent with the hypothesis that nutrient foraging is eased as nutrient supply rises in wetland plants. Under these conditions, plants can expend more of their carbon fixation on the accumulation of aboveground biomass (Levin et al. 1989). 
A second effect of increased nutrient loading is that the organic decomposition rate of litter lying at the surface and soil organic matter rises, not only for coastal wetlands, but also for a variety inland wetlands (Harris et al. 1962; Eggelsmann 1976; Morris and Bradley 1999; Coûteaux et al. 1995; Bragazza et al. 2006; Laursen 2004; Mack et al. 2004; Franzen 2006; Wigand et al. 2009). Organic-rich freshwater marsh (Panicum hemitomon) soil exposed to a chronic influx of nutrient-rich river water was more decomposed, and the soil strength was reduced by $50 \%$, compared with marsh soil substantively identical except that nutrient-poor rain was the source of freshwater (Swarzenski et al. 2008). An analysis of a 30-year nutrient addition experiment in an east coast (US) salt marsh showed that organic soil accumulation did not increase in the fertilized plots and that soil strength and elevation declined (Turner et al. 2009). Some of this carbon loss is because the bacteria use carbon as the electron donor to form nitrogen gas (denitrification) under anaerobic conditions (Hamersley and Howes 2005). Anaerobic metabolism may also result in the increased formation of hydrogen sulfide, nitrous oxide, and methane. Wigand et al. (2009) describe, for example, a pattern of rising soil respiration in a variety of Rhode Island salt marshes as nitrogen loading increased among locations even though the standing stock of belowground biomass declined. The result of nutrient enrichment may be, therefore, that soil carbon is depleted because less belowground organic matter is produced and because a higher proportion of belowground production is metabolized.

The effect of increased nutrient loadings on wetland ecosystem trajectories, of course, may take years to become apparent. Qualls and Richardson (2008), for example, found that decomposition of leaves from the dominant freshwater marsh macrophyte (Cladium jamaicense Pers.) was greater with phosphorus enrichment after 1 year, whereas Newman et al. (2001) report no change in litter decomposition with nutrient enrichment after 3 years. Holm (2006) found that nitrogen+phosphorus additions in a $P$. hemitomon marsh did not stimulate decomposition in litter bags placed on the soil surface. Organic matter decomposition in in-growth chambers placed in the soil, however, was faster in the nutrient-enriched chambers after 2 years when compared to organic decomposition in the control chambers. The responses to increased nutrient loadings may also be nonlinear. Penton and Newman (2007, 2008), for example, suggested that there was a $P$ load threshold above which decomposition was triggered and where slower peat accumulation and elevation changes occurred.

These results support the conclusion that multiyear experiments are needed to understand the relationships between soil sustainability and increased nutrient loading to wetlands. Some significant questions need to be addressed, therefore, about how much and how rapidly soil strength is affected by less belowground biomass and higher organic decomposition rates. Is there a significant change in soil strength and, if there is, how does the trajectory of soil strength decline as nutrient loading increases? How do the results of an increased loading of nitrogen, the primary limiting nutrient of the aboveground biomass (Morris 1991), compare to an increased loading of phosphorus, which can have the effect of lowering belowground biomass and increasing soil metabolism (Darby and Turner 2008a, b; Sundareshwar et al. 2003)?

I report herein on how soil strength changes in the upper $100 \mathrm{~cm}$ of salt marshes after 14 different combinations of $\mathrm{N}$ and $\mathrm{P}$ were added to replicated plots. These experiments lasted from 1 to 5 years. I then discuss the implications for marsh restoration and conservation, with attention to some wetland restoration projects near New Orleans, LA.

\section{Methods}

The strength of salt marsh soils in coastal Louisiana salt marshes treated with and without different nutrient additions was measured with a Dunham E-290 Hand Vane Tester. This handheld instrument measures the maximum resistance (torque) when a rod fitted with vanes is rotated at different soil depths. The in situ readings of the peak shear vane strength are recorded on a calibrated scale built into a head assembly. The head assembly is directly attached to a steel rod fitted with $25.4 \times 50.8-\mathrm{mm}$ vanes at the terminal end. A handle is used to both insert the vane to the desired depth and to apply the shearing torque. No correction for the skin friction of the extension rods (done with a shaft without vanes) was routinely performed on individual measurements, but selected measurements indicate that that the skin friction was always less than $0.1 \mathrm{kPa}$ (kilopascal). Measurements within the control and treatment plots at $10-\mathrm{cm}$ intervals were compared to obtain the percent shear vane strength of the plots with nutrient additions. There were a minimum of three and a maximum of six vertical profiles for each plot. The mean \pm 1 standard error $(\mu \pm 1 \mathrm{SE}$; $p<0.1)$ was calculated for each $10-\mathrm{cm}$ increment.

Shear vane measurements were made in treatment plots fertilized with various amounts and kinds of nitrogen, phosphorus, or nitrogen + phosphorus treatments $(+\mathrm{N},+\mathrm{P}$, $+\mathrm{N}+\mathrm{P}$, respectively; Table 1). The plot locations were in a salt marsh within $1 \mathrm{~km}$ of the Louisiana Universities Marine Consortium (LUMCON) at Cocodrie, LA, where the percent organic matter in the upper $30 \mathrm{~cm}$ was $21.9 \pm$ $2.4 \%$ (unpublished results). All sampled locations are at least $10 \mathrm{~m}$ inland of the streamside levee marsh where the marsh soils are at least $1 \mathrm{~m}$ deep and overlay deltaic 


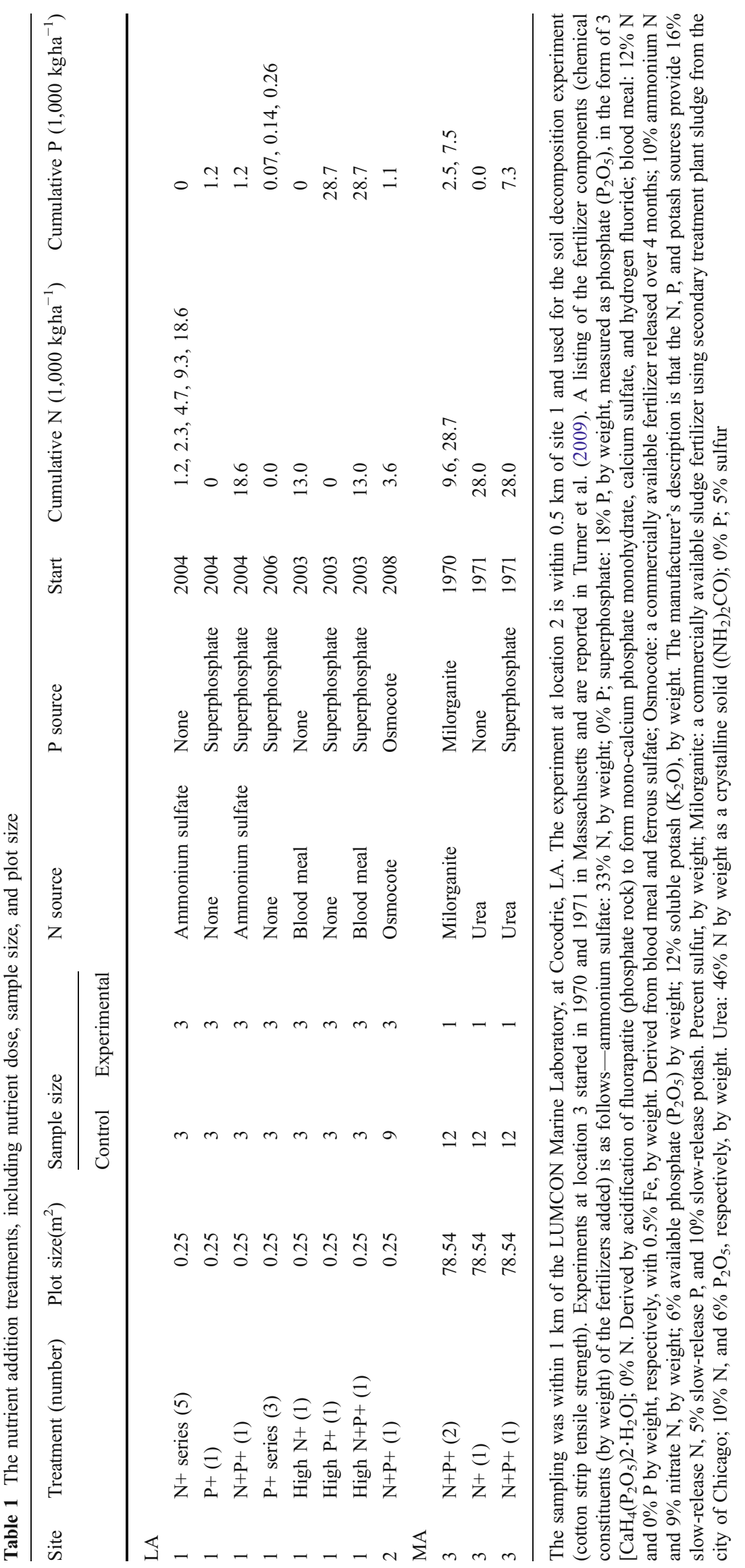


mineral soils. Measurements were made in 24 of the thirtysix $0.25-\mathrm{m}^{2}$ plots described by Darby and Turner (2008b), which were started in 2004 and continued with 3 to 4 equal doses annually to arrive at the cumulative doses shown in Table 1. The doses in these 24 plots include triplicate treatments of 5 different levels of nitrogen additions $(+\mathrm{N}), 1$ phosphorous treatment $(+\mathrm{P}), 1+\mathrm{N}+\mathrm{P}$ treatment, and 1 control set (in triplicate). Darby and Turner (2008a) harvested plants from 24 of these plots in 2005 (21 treatments and 3 control plots). Measurements of plant canopy height and stem density in 2006 and 2008 showed no difference in the same plot compared to the 2005 values. The location of the shear vane measurements did not overlap where Darby and Turner (2008a) extracted soil cores in 2005 to measure root density. All plots have had no intentional disturbances by our field survey team.

There were twelve $0.25-\mathrm{m}^{2}$ plots of triplicate treatments of control, $+\mathrm{N},+\mathrm{P}$, and $+\mathrm{N}+\mathrm{P}$ treatments that began in 2003. These latter plots had similar $+\mathrm{N}$ treatment as in the plots started in 2004, but with higher $+\mathrm{P}$ treatments. Three additional replicated $+\mathrm{P}$ treatments (plus controls) were started in 2006 for a total of 48 plots at one marsh, of which 9 were control plots and 39 (13 different treatments) were experimental plots. The total number of triplicate treatments was, therefore, six different $+\mathrm{N}$ treatments, five different $+\mathrm{P}$ treatments, and two different $+\mathrm{N}+\mathrm{P}$ treatments. The range of the cumulative dose of $\mathrm{N}$ and $\mathrm{P}$ was 1,200 to $18,600 \mathrm{~kg}$ $\mathrm{Nha}^{-1}$ and 70 to $28,700 \mathrm{kgPha}^{-1}$.

Vertical profiles of shear vane strength were made at $10-\mathrm{cm}$ increments in each of the control and in the triplicate treatment plots in November 2008. A one-way analysis of variance with a Tukey's multiple comparisons test was used to determine whether there were significant differences in soil strength between the nine control and triplicate treatment plots and among different kinds of treatment plots $(p<0.05)$ (Graphpad Software Inc. 2005). The values for the treatment plots were expressed as a percent of the values in the control plots $(\mu \pm 1 \mathrm{SE} ; n=3)$. A regression of the percent of the control plot versus cumulative $\mathrm{N}$ or cumulative $\mathrm{P}$ addition was conducted where $\log _{10} Y=a+b x$, and $p<0.05$. Shear vane values obtained from the 13 treatments located in the 1 contiguous marsh were compared to the data described in Turner et al. (2009) for 4 different nutrient enrichment treatments conducted for 30 years at the Great Sippewissett Marsh, Sippewissett, MA.

An additional $+\mathrm{N}+\mathrm{P}$ treatment was started in 2008 (plus control plots) located within $0.5 \mathrm{~km}$ of the experimental treatments near LUMCON. These treatment plots were treated with a cumulative nitrogen and phosphorus dose (Osmocote) of 3,600 and 1,100 $\mathrm{kgha}^{-1}$, respectively. This site was within $30 \mathrm{~m}$ of where soil decomposition measurements were made in $0.5 \times 2-\mathrm{m}$ plots. The loss of the tensile strength of canvas strips buried between the surface and
$80 \mathrm{~cm}$ was used as a surrogate measure of soil decomposition. The methods of Slocum et al. (2009) were used. Briefly, three $80-\mathrm{cm} \times 10$-cm strips of artist's canvas were inserted into the marsh soil within $2 \times 0.5-\mathrm{m}$ plots in September 2009 and retrieved after 2 weeks. Additional strips were inserted and removed at the beginning of the experiment to serve as "disturbed control" treatments. A 2 -cm $\times 10-\mathrm{cm}$ strip was at 10 -cm intervals from each of three replicates from both control and treatment plots, and its tensile strength measured with a Mecmesin MultiTest 1-D digital motorized test standard and a basic force gage equipped with spring-loaded roller grips. Measurements were made at room temperature. The tensile strength of the disturbed control strips was subtracted from the tensile strength of the canvas strips left in the treatment plots to calculate the percent daily change in tensile strength.

Data on plant aboveground biomass (gram per square meter) and stem density (number per square meter) at these $0.25-\mathrm{m}^{2}$ plots were collected at the Louisiana study site in September 2005. The aboveground data are described in Darby and Turner (2008b). The stem density in these same plots and five additional ones at the same location were resampled in November 2008, together with shear vane measurements as described above.

\section{Results}

The down core profiles of shear vane strength in the control plots show that soil strength at the surface is approximately $11 \mathrm{kPa}$ and declines to about $4.5 \mathrm{kPa}$ between 20 and $50 \mathrm{~cm}$ and then rises to $11 \mathrm{kPa}$ at $100 \mathrm{~cm}$ (Fig. 1). The data analyses were restricted to the $0-$ to $100-\mathrm{cm}$ layer because stiff resistance to the penetration of the shear vane begins at around $120 \mathrm{~cm}$ in these marshes.

The downcore shear vane strength measurements in soils receiving the $+\mathrm{N}+\mathrm{P}$ treatments are shown in Fig. 1. These treatment plots received a cumulative $\mathrm{N}$ dose that is the highest of all the Louisiana marsh treatments and is in the middle of the range of the cumulative $\mathrm{P}$ dose (Table 1). There was no difference in the shear vane strength between

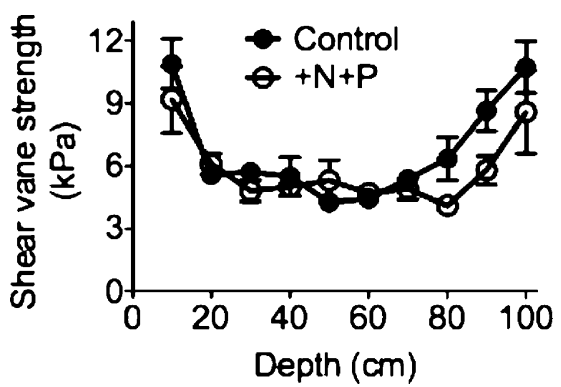

Fig. 1 The shear vane strength (kilopascal; $\mu \pm 1 \mathrm{SE}$ ) for replicated control and $+\mathrm{N}+\mathrm{P}$ treatment plots for the 10 - to $100-\mathrm{cm}$ soil depth 

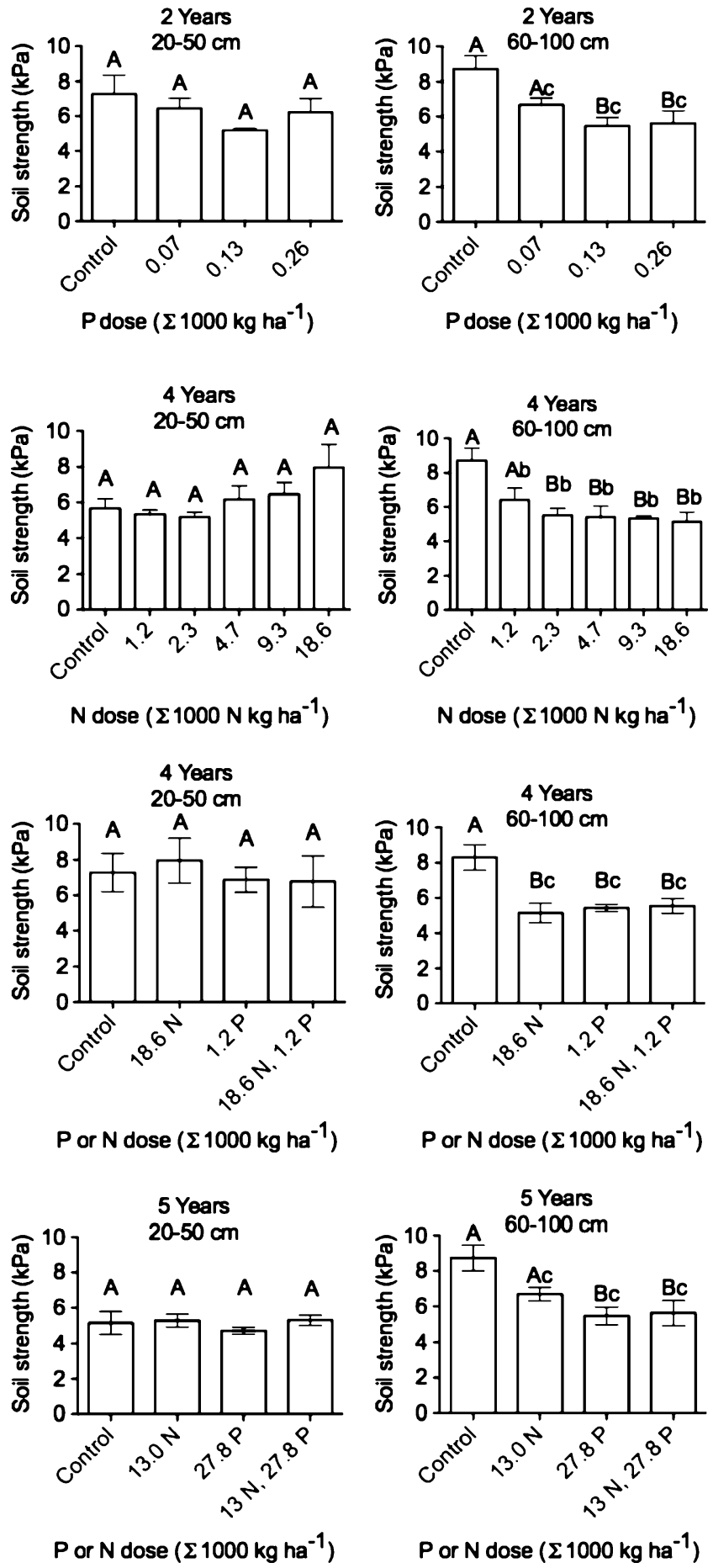

Fig. 2 The average shear vane strength (kPa; $\mu \pm 1 \mathrm{SE} ; n=3)$ at 20 to 50 (left side) and at $60-$ to $100-\mathrm{cm}$ soil depth (right side) versus the treatment conditions in different plots $(C=$ control; $+N=$ nitrogen; $+P=$ phosphorus). Means with the same lettering are not statistically different from each other (level of significance $<0.05$ ). The cumulative years of treatment and cumulative $\mathrm{N}, \mathrm{P}$, or NP added are indicated in each graph. Note that the shear vane in the control sites are the same in all upper and all lower soil layers and that the shear vane strength in the 4year experiment is from the same plot $\left(18.6 \times 1,000 \mathrm{kgN} \mathrm{ha}{ }^{-1}\right.$ treatment) in two adjoining panels (second and third rows) control and $+\mathrm{N}+\mathrm{P}$ treatments in the upper soil profile $(20-$ $50 \mathrm{~cm}$ ), but the soil strength was reduced by about $21 \%$ in the $60-$ to $100-\mathrm{cm}$ soil layer of the $+\mathrm{N}+\mathrm{P}$ treatment plots.

The focus of the following discussion is about how soil strength in the upper (top) and deeper (bottom) soil layer differs between control and nutrient-amended plots. The shear vane strength in the $60-$ to $100-\mathrm{cm}$ layer, but not the layer above, declines with higher loading of either $\mathrm{N}$ or $\mathrm{P}$ (Fig. 2). There was no statistically significant difference between soil strength in the control and treatment plots in the surface layer (Fig. 2, left, four panels). The shear vane strength in the bottom layer, in contrast, was always lower than that in the control plots when $\mathrm{P}$ and $\mathrm{N}$ loadings were at least $130 \mathrm{kgPha}^{-1} \mathrm{P}$ or $2,000 \mathrm{~kg} \mathrm{Nha}^{-1}$ (Fig. 2, right, four panels). The effect of $\mathrm{N}$ and $\mathrm{P}$ additions was not significantly different than if $\mathrm{P}$ was added separately in the 5-year-old treatment plots, but not in the 4-year-old treatment plots. The relationship between the cumulative $+\mathrm{N},+\mathrm{P}$, or $+\mathrm{N}+\mathrm{P}$ loading and the relative change in shear vane strength is in Fig. 3. There was a significant relationship between the cumulative nutrient loading and the loss of soil strength, amounting to a maximum of about $35 \%$.

The soil strength in the upper layer of the Louisiana marshes remained relatively constant compared to that in

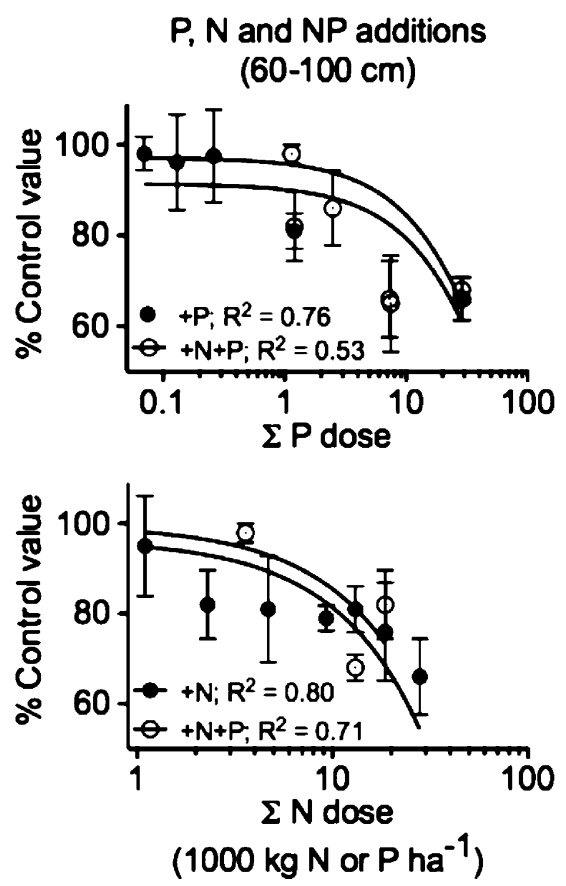

Fig. 3 The average shear vane strength at $60-$ to $100-\mathrm{cm}$ soil depth as a percent of the value in the control plots versus the cumulative $\mathrm{N}$ and $\mathrm{P}$ load $\left(\Sigma 1,000 \mathrm{kgha}^{-1}\right)$ for plots fertilized with $+\mathrm{P}$ or with $+\mathrm{N}+\mathrm{P}$ (upper panel) or plots fertilized with $+\mathrm{N}$ and $+\mathrm{P}+\mathrm{N}$ (lower panel). The data are fit to a regression equation of the form $\log Y=a+b x$. The coefficient of determination $\left(R^{2}\right)$ is shown in each graph, where n.s. $=$ not significant 


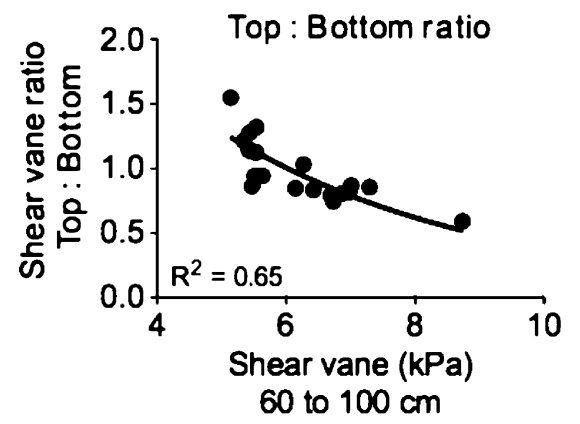

Fig. 4 The ratio of the shear vane strength at the top $(20$ to $50 \mathrm{~cm})$ and bottom (60 to $100 \mathrm{~cm}$ ) of a soil profile versus the shear vane strength at the bottom. The data are fit to a regression equation of the form $\log Y=a+b x$. The coefficient of determination $\left(R^{2}\right)$ is 0.65 and $p<0.05$

the soil beneath. As nutrient amendments caused the shear vane strength to decrease in the lower layer, the ratio of soil strength in the two layers (top/bottom) doubled from around 0.7 to 1.5 (Fig. 4).

There is a strong positive relationship between aboveground biomass and stem density $\left(R^{2}=0.84\right.$; Fig. 5, left panel), indicating that either biomass or stem density is a relative surrogate for nitrogen loading, because the accumulation of aboveground biomass is primarily limited by nitrogen (Darby and Turner 2008b). There was an inverse relationship between shear vane strength (at $60-$ to $100-\mathrm{cm}$ soil depth; relative to the control plots) and stem density that is strongly linear $\left(R^{2}=0.66\right.$; Fig. 5 , right panel). This result is consistent with the results in Fig. 2, which show a declining soil strength with higher nutrient loading.

The tensile strength of canvas strips placed in a nearby marsh was $16 \%$ to $48 \%$ lower in the fertilized plot, compared to the control plot (Fig. 6), implying that the nutrient amendment caused a significantly higher decomposition down to $60 \mathrm{~cm}$, and perhaps deeper. These results are from one experiment and there are, undoubtedly, strong variations during the year.

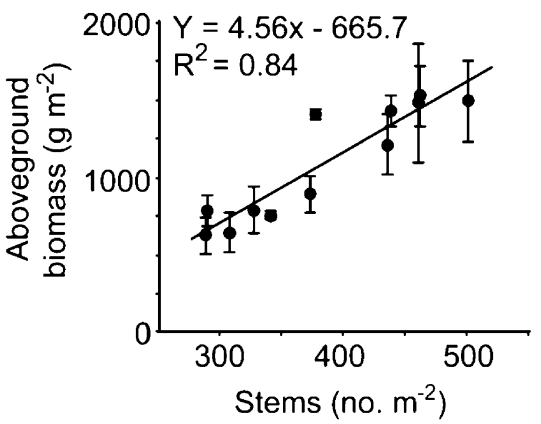

Fig. 5 Relationships between stem density (number per square meter) and both aboveground biomass (left; gram per square meter; $\mu \pm 1 \mathrm{SE}$ ) and shear vane strength at $60-$ to $100-\mathrm{cm}$ soil depth (right). The shear vane data were converted to the value in the treatment plot as a percent of that in the control plots ( $\mu \pm 1 \mathrm{SE})$. The data in the left panel

\section{Discussion}

It appears that the effects of the nutrient additions to these salt marshes are to increase the aboveground biomass (Darby and Turner 2008b), lower belowground biomass (Darby and Turner 2008a, b), increase decomposition rates (Fig. 6), and reduce soil strength (Figs. 1, 2, 3, and 4). These are interrelated consequences embedded within a suite of consequences. If soils oxidize and there are few roots and rhizomes, then the soil will become weaker. Some of these results could be inferred as a possibility based on the results of Morris and Bradley's (1999) experiments in a mineral-rich South Carolina salt marsh. Morris and Bradley (1999) found that $+\mathrm{N}+\mathrm{P}$ fertilization (ammonium nitrate and phosphate; Huang and Morris 2005) for 12 years increased soil respiration by $36 \%$. Morris et al. (2005), however, also describe a rise in surface elevation in the fertilized plots because of the accumulation of inorganic material in the mineral-rich marsh that they sampled. Elevation changes from soil decomposition (subsidence) seem more likely to occur in organic-rich sediments with a relatively small inorganic source for deposition. Other factors besides soil inorganic content will modify the effects of higher nutrient loading on soil organics, e.g., tidal range occupied, climate, and flooding cycles. Temperature, for example, has a well-established direct effect on soil organic decomposition and root turnover (Gill and Jackson 2000), and salt marsh plants have some physiological abilities to adapt to flooding and salt stress (Mendelssohn et al. 1981). It is unlikely, therefore, that all marshes will respond equally to similar increases in nutrient loads.

Nutrient additions caused significant changes in the soils of these Louisiana marshes between $60-$ and $100-\mathrm{cm}$ soil depth. It is interesting to ask why there is an effect at this deeper layer, and not in the surface layer. The results of sediment dating of these marshes $\left({ }^{137} \mathrm{Cs}\right.$ dating method;

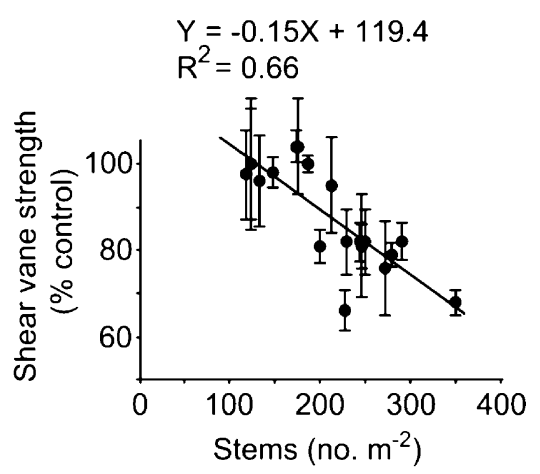

are from 11 different nutrient treatments (in triplicate) sampled in September 2005 and described in Darby and Turner (2008a). The data in the right panel are from 16 triplicate plots sampled in November 2008. $p<0.01$ in both graphs 


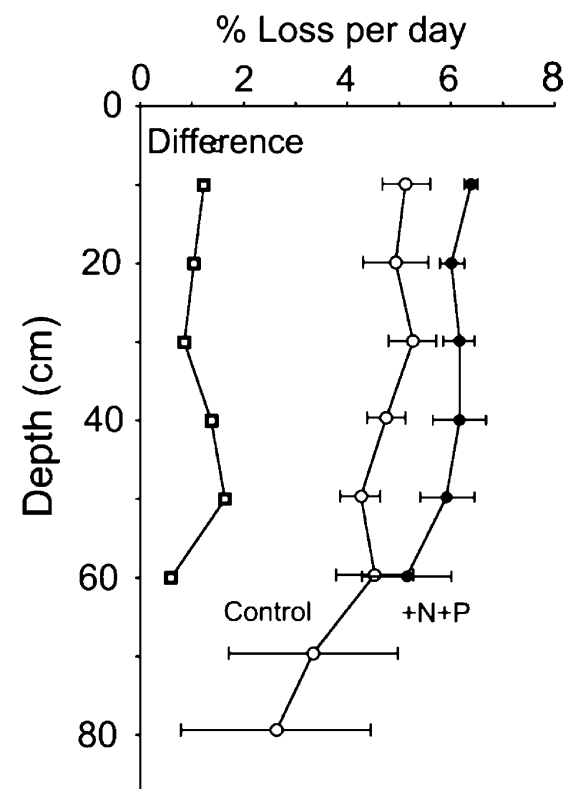

Fig. 6 The change in tensile strength of buried canvas (percent loss per day; $\pm 1 \mathrm{SE}$ )

Milan et al. 1995) indicate that the accretion rate since $1963 / 1964$ was $0.60 \mathrm{cmyear}^{-1}$. If we assume that accretion below $60 \mathrm{~cm}$ is nearly the same as above this layer, and disregarding compaction, then the $60-\mathrm{cm}$ soil depth is at least 100 years old and contains organic matter formed before major water quality changes occurred (Parsons et al. 2006; Broussard and Turner 2009). Perhaps the exposure to a new source of phosphorus speeds up the soil microbes enough to cause the loss of soil strength, as organic matter is decomposed (e.g., Sundareshwar et al. 2003). Perhaps a key issue is how metabolism in the rhizosphere is affected by higher nutrient loads. Plant-mediated phosphorus metabolism is a potentially significant factor at these depths, even if the vertical distribution of biomass declines with depth. Although the density of rhizomes declines quickly below $30 \mathrm{~cm}$ in these marshes, for example, the fine roots penetrate much deeper and may have relatively higher metabolic activity per weight for nutrient uptake than at the surface. Reimold (1972), for example, demonstrated that the maximum phosphorus uptake of ${ }^{32} \mathrm{P}$-labeled inorganic phosphate inserted into Georgia salt marsh soil was at $100-\mathrm{cm}$ soil depth. Nutrient loading in recent years, therefore, might have an effect on the salt marsh organic matter that accumulated over several hundred years.

The results of these 5-year-long experiments in Louisiana might be compared to the results from the 30+ year experiments conducted at the Sippewissett marshes (MA). The nutrient amendments were qualitatively different at the two locations (Table 1), and the shear vane strength was measured at only $50 \mathrm{~cm}$ in the Sippewissett marshes, and not over the 0 to 100 soil profile measured in
Louisiana. The direction and scale of the changes at Sippewissett (Fig. 7) is similar to what was observed in Louisiana: the shear strength declined with increasing nutrient load and by significant amounts for the same amount ( $20 \%$ to $30 \%$ at the highest rate).

Deegan et al. (2010) added N and P to the flooding tides of a salt marsh in Massachusetts to create a cumulative load over 2 years of $1,200 \mathrm{~kg} \mathrm{~km}^{2} \mathrm{~N}$ and $90 \mathrm{~kg} \mathrm{~km}^{2} \mathrm{P}$. These loading rates are towards the low end of what is described in the results reported herein. They found significant changes in the microbial, infaunal, and benthic microalgal community, as well as altered food web interactions. The loading rates Deegan et al. used were within the range they anticipated to result from the "addition of 1,000 houses in the upland watershed of each of the nutrient-enriched creeks". One thousand houses will be there for decades, of course, thus the effects of nutrient loading is appropriately examined using the cumulative long-term loading rate, as well as the annual rate.

The seemingly mild or nonexistent differences in soil strength in the bottom layer measured in the $+\mathrm{N}$ or $+\mathrm{P}$ treatment plots, or in combination (Fig. 2), are an interesting observation that deserves further scrutiny. It may be that metabolic activity at 60 to $100 \mathrm{~cm}$ is so intensely constrained by either $\mathrm{N}$ or $\mathrm{P}$ that a synergistic response is not inevitable. White and Reddy (2000) described some of the effects of increased $\mathrm{P}$ loading on $\mathrm{N}$ mineralization in the Everglades, but I am unaware of relevant studies of the effect of $\mathrm{N}$ loading on $\mathrm{P}$ cycling or how either affects soil strength.

One strong implication of these observations is that the widespread increases in nutrient loadings to coastal waters (NRC 2000) may alter marsh ecosystem functions and perhaps compromise the long-term stability of coastal marshes by increasing belowground organic matter decomposition rates and by reducing root production resulting in a net decline in soil strength. In addition, the increased

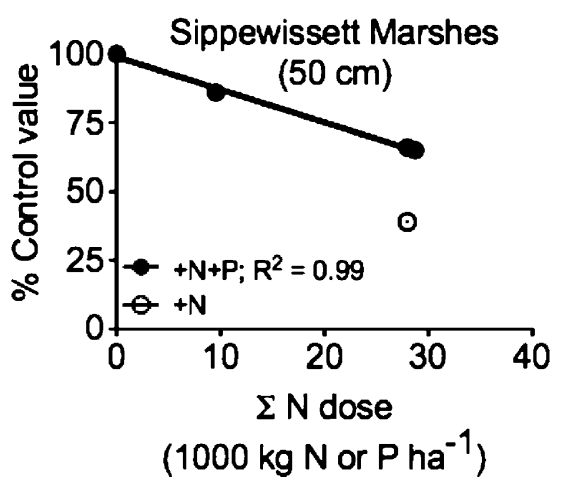

Fig. 7 Changes in soil strength as a percent of that in the control marsh at the long-term sewage-amended salt marsh at Sippewissett, MA. The data are described in Turner et al. (2009), but not presented graphically. $p<0.01$ 
biomass aboveground will also result in more "tug" on the belowground biomass during storms or from strong tidal currents. As a result of these changes, the chronic degradation of marsh organic matter may not be visually identified or expressed until the aboveground portion of the plant is ripped out of its substrate in a quick transition from marsh to mud flat or open water.

The long-term effects of increased nutrient loading on coastal soils are also of concern because the anticipated climate changes will result in an acceleration of sea level rise. Coastal marshes maintain their vertical position within the upper portion of the local tidal range through the accumulation of both inorganic and organic materials. The accumulation of organic matter at the present rate of sea level rise controls the vertical accretion rate in organic-rich salt marshes (Turner et al. 2000). Soil elevation may be lowered and to the detriment of the plant's existence if either the root production is decreased or the decomposition of accumulated organic matter is accelerated enough so that the net organic accumulation is less than the relative sea level rise or, in particular, with the predicted acceleration in sea level rise. The anticipated additional rise in atmospheric $\mathrm{CO}_{2}$ may, however, increase belowground biomass (Langley et al. 2009), whereas accelerated sea level rise will be an additional stressor. Teasing out the interrelationships is an appropriate challenge to address with field studies.

A decline in soil strength with nutrient enrichment suggests, but does not prove, that hurricanes will more easily tear the marsh apart at its weakest area, which is about 40 to $70 \mathrm{~cm}$ deep in the plots studied here. This may be the cause of the loss of $12 \%$ of the wetlands $\left(106 \mathrm{~km}^{2}\right.$; Turner 2010) in the flow path of the Caernarvon river diversion, located downstream from New Orleans, and on the western side of where Hurricanes Katrina and Rita passed by this city in 2005 . The nutrients in the diverted river water provide $60 \%$ to $71 \%$ of the total nitrogen load to all of Breton Sound (Hyfield et al. 2008) and bring the cumulative $\mathrm{N}$ load for the entire area to within range of the $10 \%$ soil strength loss shown in Fig. 3. There would be regional variations in loading that would be many times higher closer to the diversion structure. The Caernarvon diversion was constructed to strengthen the marsh and prevent further losses, but the reference area to the east, separated from the diversion water flow path by LA Highway 300, and also in the path of Hurricane Katrina, had much less marsh loss from these two hurricanes (Turner 2010). On the west bank of the Mississippi River, wetland loss from Hurricane Katrina was higher near the Naomi and W. Pt. la Hache Mississippi River diversions and absent a few kilometers away from them (Turner 2010). These observations suggest that this part of Louisiana's wetland restoration program may have had an unexpected negative outcome and support the suggestion of Swarzenski et al.
(2008) that the widespread decline of freshwater marshes in the Lake Penchant area is related to the inflow of nutrient-rich Atchafalaya riverwater during periods of high discharge.

The societal costs of building and operating these diversions are considerable. A diversion costs several hundred million dollars (U.S. Government Accountability Office 2007), the cost of restoring or creating wetlands is at least $\$ 179,000 \mathrm{ha}^{-1}$ (Turner 2010), and one estimate of the storm protection values specific to Louisiana is $\$ 1,479 \mathrm{ha}^{-1}$ year $^{-1}$ (Costanza et al. 2008). An estimate of the economic value of these wetland losses from Hurricane Katrina and Rita over 20 years, therefore, is in the range of several hundred million, to several billion dollars, and so I agree with Swarzenski et al. (2008) that a quantitative evaluation of the relations between river diversions and wetland soil ecosystems is desirable. Indeed, the consequences of implementing a proposed wetland restoration action that is based on unsupportable assumptions may be to lose wetlands, not sustain them.

The modern day water quality in the Mississippi River may, therefore, compromise attempts to use diversions of the Mississippi River to restore coastal wetlands where the receiving area has organic soils, which is most of Louisiana's coastal wetlands (Chabreck 1972). Whatever benefit results from increases in the inorganic sediment supply should be weighed against the impact of also adding nutrients that weaken the soils. With that in mind, it is worth pointing out that reducing the size of the largest low oxygen zone in the western Atlantic (the "Dead Zone") is also dependent on reducing nitrogen loading by the Mississippi River to the offshore zone (Rabalais et al. 2002, 2007). The primary determinant of the rise in nitrate concentration in the Mississippi River is land use changes in the watershed since the 1850s, and particularly since the 1950s (Turner and Rabalais 2003; Broussard and Turner 2010). Restoration of Louisiana's coastal wetlands, shrinking the Dead Zone, and sustaining New Orleans are, therefore, intimately linked through improvements in the Mississippi River water quality - something that must take place inland, far from the coast.

Acknowledgments Support was provided by the NOAA Coastal Ocean Program MULTISTRESS Award No. NA16OP2670 to Louisiana State University and from the Coastal Restoration and Enhancement through Science and Technology program. I thank J. Tripp, Environmental Defense Fund, for asking the pregnant question about the relationships between nutrient loading and soil quality, C. Swarzenski for comments on an earlier draft, and D. Daigle and C. Milan for their editorial review. The many, many constructive suggestions made by two anonymous reviewers are appreciated.

Conflict of Interest I have no financial relationship with the organization that sponsored the research. I have full control of all primary data and agree to allow the journal to review the data if requested. There are no potential conflicts in the use of the data or financial conflicts. 


\section{References}

Bragazza, L., C. Freeman, T. Jones, R. Håkan, J. Limpens, N. Fenner, T. Ellis, R. Gerdol, M. Håjek, P. Iacumin, L. Kutnar, T. Tahvanainen, and H. Toberman. 2006. Atmospheric nitrogen deposition promotes carbon loss from peat bogs. Proceedings of the National Academy of Sciences of the United States of America 103: 19386-19389.

Broussard, W., and R.E. Turner. 2009. A century of changing land use and water quality relationships in the continental U.S. Frontiers in Ecology and the Environment 7: 302-307.

Chabreck, R. 1972. Vegetation, water and soil characteristics of the Louisiana coastal region. Louisiana Agricultural Experiment Station Bulletin 664. Baton Rouge, Louisiana.

Coûteaux, M.-M., P. Bottner, and B. Berg. 1995. Litter decomposition, climate and litter quality. Trends in Ecology \& Evolution 10: 6366.

Costanza, R., O. Pérez-Maqueo, M.L. Martinez, P. Sutton, S.J. Anderson, and K. Mulder. 2008. The value of coastal wetlands for hurricane protection. Ambio 37: 241-248.

Darby, F.A., and R.E. Turner. 2008a. Effects of eutrophication on salt marsh roots, rhizomes, and soils. Marine Ecology Progress Series 363: 63-70.

Darby, F.A., and R.E. Turner. 2008b. Below- and aboveground biomass of Spartina alterniflora: Response to nutrient addition in a Louisiana salt marsh. Estuaries and Coasts 31: 326-334.

Deegan, L.A., and 18 co-authors. 2010. Susceptibility of salt marshes to nutrient enrichment and predator removal. Ecological Applications 17: 542-563.

Eggelsmann, R. 1976. Peat consumption under influence of climate, soil condition, and utilization. In Proceedings International Peat Congress. 1: 233-247. International Peat Society Poznan, Poland.

Franzen, L.G. 2006. Increased decomposition of subsurface peat in Swedish raised bogs: Are temperate peatlands still net sinks of carbon? Mires and Peat 3: 1-16.

Gill, R.A., and R.B. Jackson. 2000. Global patterns of root turnover for terrestrial ecosystems. The New Phytologist 147: 13-31.

Graphpad Software Inc. 2005. Graphpad prism, ver. 4.0. CA: Graphpad Software, Inc.

Hamersley, M.R., and B.L. Howes. 2005. Coupled nitrificationdenitrification measured in situ in a Spartina alterniflora marsh with a $\left(\mathrm{NH}_{4}^{+}\right)-\mathrm{N}-15$ tracer. Marine Ecology Progress Series 299: $123-135$.

Harris, C.I., H.T. Erickson, N.K. Ellis, and J.E. Larson. 1962. Waterlevel control in organic soil, as related to subsidence rate, crop yield, and response to nitrogen. Soil Science 94: 158-161.

Holm, G.O. 2006. Nutrient constraints on plant community production and organic matter accumulation of subtropical floating marshes. $\mathrm{Ph} . \mathrm{D}$. dissertation, Louisiana State University, Baton Rouge, Louisiana.

Huang, X., and J.T. Morris. 2005. Distribution of phosphatase activity in marsh sediments along an estuarine salinity gradient. Marine Ecology Progress Series 292: 75-83.

Hyfield, E.C.G., J.W. Day, J.E. Cable, and D. Justic. 2008. The impacts of re-introducing Mississippi River water on the hydrologic budget and nutrient inputs of a deltaic estuary. Ecological Engineering 32: 347-359.

Langley, J.A., K.L. McKee, D.R. Cahoon, J.A. Cherry, and P. Megonigal. 2009. Elevated $\mathrm{CO}_{2}$ stimulates marsh elevation gain, counterbalancing sea-level rise. Proceedings of the National Academy of Sciences of the United States of America 106: 61826186.

Laursen, K.R. 2004. The effects of nutrient enrichment on the decomposition of belowground organic matter in a Sagittaria lanciffolia-dominated oligohaline marsh. M.S. thesis, Louisiana State University, Baton Rouge, Louisiana.

Levin, S.A., H.A. Mooney, and C. Field. 1989. The dependence of plant root:shoot ratios on internal nitrogen concentration. American Journal of Botany 64: 71-75.

Lovelace, J.K., B.F. McPherson. 1998. Effects of Hurricane Andrew (1992) on wetlands in southern Florida and Louisiana. U.S. Geological Survey, National Water Summary on Wetland Resources. U.S.G.S. Water Supply Paper 2425. http://water. usgs.gov/nwsum/WSP2425/andrew.html. Accessed 16 Feb 2010.

Mack, M.C., E.A.G. Schuur, M.S. Bret-Harte, R. Shaver, and S. Chaplin III. 2004. Ecosystem carbon storage in arctic tundra reduced by long-term nutrient fertilization. Nature 431: 440-443.

Mendelssohn, I.A., K.L. McKee, and W.H. Patrick Jr. 1981. Oxygen deficiency in Spartina alterniflora roots: Metabolic adaptation to anoxia. Science 214: 439-441.

Milan, C.S., E.M. Swenson, R.E. Turner, and J.M. Lee. 1995. Accumulation rates estimated from ${ }^{137} \mathrm{Cs}$ activity: Variability in Louisiana salt marshes. Journal of Coastal Research 11: 296307.

Morris, J.T. 1991. Effects of nitrogen loading on wetland ecosystems with particular reference to atmospheric deposition. Annual Review of Ecology and Systematics 22: 257-279.

Morris, J.T., and P. Bradley. 1999. Effects of nutrient loading on the carbon balance of coastal wetland environments. Limnology and Oceanography 44: 699-702.

Morris, J.T., P.V. Sundareshwar, C.T. Nietch, B. Kjerfve, and D.R. Cahoon. 2005. Responses of coastal wetlands to rising sea level. Ecology 83: 2869-2877.

National Research Council (NRC). 2000. Clean coastal waters. Understanding and reducing the effects of nutrient pollution. Washington: National Academy Press.

Newman, S., H. Kumpf, J.A. Laning, and W.C. Kennedy. 2001. Decomposition responses to phosphorus in an Everglades (USA) slough. Biogeochemistry 54: 299-250.

Parsons, M.L., Q. Dortch, R.E. Turner, and N.N. Rabalais. 2006. Reconstructing the development of eutrophication in Louisiana salt marshes. Limnology and Oceanography 151: 534-544.

Penton, C.R., and S. Newman. 2007. Enzyme activity responses to nutrient loading in subtropical wetlands. Biogeochemistry 84: $83-98$.

Penton, C.R., and S. Newman. 2008. Enzyme-based resource allocated decomposition and landscape heterogeneity in the Florida Everglades. Journal of Environmental Quality 37: 972976.

Qualls, R.G., and C.J. Richardson. 2008. Decomposition of litter and peat in the Everglades: The influence of $\mathrm{P}$ concentrations. In The Everglades experiments, ed. C.J. Richardson, 441-459. New York: Springer.

Rabalais, N.N., R.E. Turner, and D. Scavia. 2002. Beyond science into policy: Gulf of Mexico hypoxia and the Mississippi River. Bioscience 52: 129-142.

Rabalais, N.N., R.E. Turner, B.K. Sen Gupta, D.F. Boesch, P. Chapman, and M.C. Murrell. 2007. Hypoxia in the northern Gulf of Mexico: Does the science support the plan to reduce, mitigate and control hypoxia? Estuaries and Coasts 30: 753-772.

Reimold, R.J. 1972. The movement of phosphorus through the salt marsh cord grass, Spartina alterniflora Loisel. Limnology and Oceanography 17: 606-611.

Swarzenski, C.M., T.W. Doyle, B. Fry, and T.G. Hargis. 2008. Biogeochemical response of organic-rich freshwater marshes in the Louisiana delta plain to chronic river water influx. Biogeochemistry 90: 49-63.

Slocum, M.G., J. Roberts, and I.A. Mendelssohn. 2009. Artist canvas as a new standard for the cotton-strip assay. Journal of Plant Nutrition and Soil Science 172: 71-74. 
Sundareshwar, P.V., J.T. Morris, E.K. Koepfler, and B. Formwalt. 2003. Phosphorus limitation of coastal ecosystem processes. Science 299: 563-565.

Turner, R.E. 2010. Doubt and the values of an ignorance-based world view for wetland restoration: Coastal Louisiana. Estuaries and Coasts 32: 1054-1068.

Turner, R.E., J.J. Baustian, E.M. Swenson, and J.S. Spicer. 2006. Wetland sedimentation from hurricanes Katrina and Rita. Science 314: 449-452.

Turner, R.E., B.L. Howes, J.M. Teal, C.S. Milan, E.M. Swenson, and D. Goehringer-Toner. 2009. Salt marshes and eutrophication: An unsustainable outcome. Limnology and Oceanography 54: 16341642.

Turner, R.E., and N.N. Rabalais. 2003. Linking landscape and water quality in the Mississippi River Basin for 200 years. Bioscience 53: $563-572$.
Turner, R.E., E.M. Swenson, and C.S. Milan. 2000. Organic and inorganic contributions to vertical accretion in salt marsh sediments. In Concepts and controversies in tidal marsh ecology, ed. M. Weinstein and D. Kreeger, 583-595. Dordrecht: Kluwer.

U.S. Government Accountability Office. 2007. Coastal wetlands: Lessons learned from past efforts in Louisiana could help guide future restoration and protection. Washington: U.S. Printing Office, GAO-180.

White, J.R., and K.R. Reddy. 2000. Influence of phosphorus loading on organic nitrogen mineralization of Everglades soils. Soil Science Society of America Journal 64: 1525-1534.

Wigand, C., P. Brennan, M. Stolt, M. Hoh, and S. Ryba. 2009. Soil respiration rates in coastal marshes subject to increasing watershed nitrogen loads in southern New England, US. Wetlands 29: $952-963$. 